Pesq. Vet. Bras. 37(6):561-569, junho 2017 DOI: $10.1590 / \mathrm{S} 0100-736 \mathrm{X} 2017000600005$

\title{
Experimental and iatrogenic poisoning by sodium selenite in pigs ${ }^{1}$
}

\author{
Paulo V. Peixoto ${ }^{2 *}$, Krishna D. Oliveira ${ }^{3}$, Ticiana N. França ${ }^{4}$, David Driemeier ${ }^{5}$, \\ Marcos D. Duarte ${ }^{6}$, Pedro S. Bezerra Jr ${ }^{6}$, Valíria D. Cerqueira ${ }^{6}$ and Aníbal G. Armién ${ }^{7}$
}

\begin{abstract}
Peixoto P.V., Oliveira K.D., França T.N., Driemeier D., Duarte M.D., Bezerra Jr P.S., Cerqueira V.D. \& Amién A.G. 2017. Experimental and iatrogenic poisoning by sodium selenite in pigs. Pesquisa Veterinária Brasileira 37(6):561-569. Departamento de Nutrição Animal e Pastagem, Instituto de Zootecnia, Universidade Federal Rural do Rio de Janeiro, BR-465 Km 7, Seropédica, RJ 23890-000, Brazil. E-mail: peixotop@ufrrj.br

Following a case of iatrogenic selenium poisoning in a young pig, an experimental study was carry out. Sodium selenite was orally and parenterally administered to 13 pigs that were subdivided into three groups (G1, G2 and G3). The animals in groups G1 and G3 received sodium selenite intramuscularly (IM), G1 received a comercial formula, and G3 received sodium selenite mixed with distilled water at different dosages, and those in group G2 were fed commercial sodium selenite. Acute and subacute poisoning was observed in both groups, although the onset of clinical signs was slower in group G2. Only one pig (in group G1) that had received the highest dose showed a peracute course. Apathy, anorexia, dyspnea, vomiting, muscular tremors, proprioceptive deficit, ataxia and paresis of the hind limbs progressing to the front limbs evolving to tetraplegia were observed. Postmortem findings differed whether the animals received the injected (G1 and G3) or oral (G2) sodium selenite. The liver was moderately atrophic in some animals of G2. Some of the animals in groups G1 and G3 presented with lung edema. One pig in G3 had yellowish-brown areas in the ventral horns of the cervical intumescences of the spinal cord. The most important histological changes were present in the ventral horns of the cervical and lumbar intumescences of the spinal cord. In one animal, changes were present in the brainstem and mesencephalon. The initial lesion was a perivascular and astrocyte edema that progressing to lysis and death of astrocytes and neurons. In the chronic stage of the lesions, there were extensive areas of liquefaction necrosis with perivascular lymphocytic and histiocytic infiltration and occasional eosinophils. It seems that disruption of the blood-brain barrier due to astrocyte edema is the most likely mechanism of CNS lesion.
\end{abstract}

INDEX TERMS: Sodium selenite, swine, selenium poisoning, focal symmetrical poliomyelomalacia, pathogenesis.

RESUMO.- [Intoxicação iatrogênica e experimental por selenito de sódio em suínos.] A partir de um caso de intoxicação iatrogênica por selenito de sódio injetável em suíno verificaram-se alguns aspectos patogenéticos não

\footnotetext{
${ }^{1}$ Received on November 10, 2016.

Accepted for publication on November 25, 2016.

${ }^{2}$ Departamento de Nutrição Animal e Pastagem, Instituto de Zootecnia, Universidade Federal Rural do Rio de Janeiro (UFRRJ), BR-465 Km7, Seropédica, RJ 23890-000, Brazil. *Corresponding author: peixotop@ufrrj.br

${ }^{3}$ Programa de Pós-Graduação em Medicina Veterinária, Instituto de Veterinária (IV), UFRRJ, Seropédica, RJ 23890-000, Brazil.

${ }^{4}$ Departamento de Epidemiologia e Saúde Pública (DESP), IV-UFRRJ, Seropédica, RJ 23890-000, Brazil.
}

esclarecidos, o que ensejou o estudo experimental. Selenito de sódio foi administrado pelas vias oral e parenteral a 13 suínos, subdivididos em três grupos (G1, G2 e G3). Os grupos G1 e G3 receberam selenito de sódio por via intra-

\footnotetext{
${ }^{5}$ Departamento de Patologia e Clínica Veterinária, Faculdade de Medicina Veterinária, Universidade Federal do Rio Grande do Sul (UFRGS), Av. Bento Gonçalves 9090, Porto Alegre, RS 95320-000, Brazil.

${ }^{6}$ Instituto de Medicina Veterinária, Universidade Federal do Pará (UFPA), Campus Castanhal II, BR-316 Km 61, Bairro Saudade I, Castanhal, PA 68746-360, Brazil.

${ }^{7}$ Minnesota Veterinary Diagnostic Laboratory, Department of Veterinary Population, College of Veterinary Medicine, University of Minnesota, Saint Paul, MI 551008, USA.
} 
-muscular (IM); (G1 - fórmula comercial e G3 - selenito de sódio misturado à água destilada, em diversas dosagens) e o grupo G2, por via oral (VO), misturado à ração. Quadros de evolução aguda e subaguda foram observados em todos os grupos, embora o início dos sintomas tenha sido mais lento no grupo G2. Um único porco (do grupo G1), que havia recebido a dose mais alta, apresentou evolução superaguda. Apatia, anorexia, dispneia, vômito, tremores musculares, déficit proprioceptivo, ataxia e paresia dos membros posteriores com progressão para os anteriores e evolução para tetraplegia foram observados. Os achados de necropsia foram diferentes entre os animais que receberam o selenito de sódio injetável (IM - G1 e G3) e oral (G2). Havia moderada atrofia hepática em alguns animais do G2. Parte dos animais dos grupos G1 e G3 apresentaram edema pulmonar. Em um suíno (G3) notaram-se áreas marrom-amareladas nos cornos ventrais da intumescência cervical. As alterações histológicas mais importantes ocorreram nos cornos ventrais do " $\mathrm{H}$ " medular das intumescências cervical e lombar. Em um animal, as alterações envolviam o tronco cerebral e o mesencéfalo. Inicialmente, a lesão caracterizava-se por edema perivascular e astrocitário que progredia para lise e necrose de astrócitos e neurônios. 0 estágio crônico das lesões caracterizava-se por extensas áreas de necrose liquefativa e infiltração perivascular linfocítica e histiocítica, com raros eosinófilos. Sugere-se que a ruptura da barreira hematoencefálica por edema astrocitário seja o mecanismo mais provável da lesão no SNC.

TERMOS DE INDEXAÇÃO: Suíno, intoxicação por selênio, poliomielomalácia simétrica focal, patogênese.

\section{INTRODUCTION}

The toxic effect of selenium has been studied for decades (Franke \& Moxon 1936, Schoening 1936, Beath et al. 1939, Moxon \& Rhian 1943, O'Toole et al. 1996). The discovery of selenium's role in preventing certain diseases, such as exudative diathesis in chicks (Petterson et al. 1957), hepatosis dietetica and mulberry heart disease (Andrews et al. 1968), and its important antioxidant activity as part of the glutathione peroxidase enzyme (Underwood 1983), has led to its administration to animals, resulting in a number of poisoning events during the late 1960s and early 1970s that were associated with the indiscriminate use of oral or parenteral selenium (Morrow 1968, Gabbedy \& Dickson 1969, Lambourne \& Mason 1969, Shortridge et al. 1971). In swine, a distinct condition known as focal symmetrical poliomyelomalacia of swine (FSPMS) has been observed. It is manifested by ataxia of the pelvic limbs that progresses to thoracic limb ataxia, tetraplegia and death (Harrison et al. 1983, Wilson et al. 1983, Casteel et al. 1985, Mensink et al. 1990, Stowe et al. 1992, Gomes et al. 2014). Yellowish-brown bilateral areas of the spinal cord can sometimes be observed macroscopically, especially in the ventral horns of the cervical and lumbar intumescences of the spinal cord (Harrison et al. 1983, Wilson et al. 1983, Gomes et al. 2014). Microscopically, these lesions appear as focal motor neuron necrosis, microcavitation and myelin vacuolation, in addition to hemorrhage and perivascular cuffing (Penrith \& Robinson 1996, Gomes et al. 2014). Hence, the pathogenesis of FSPMS still remains a mystery, and the toxic dynamic of selenium lacks comprehensive explanations. The basis for the lesion distribution pattern in the spinal cord is also unclear. This study was initially motivated by a case of iatrogenic poisoning in a young swine that was referred to the Large Animal Veterinary Hospital of the Federal Rural University of Rio de Janeiro (UFRRJ) for a post-mortem examination. In 1993, a young male Landrace $x$ large white pig received repeated doses of commercial sodium selenite for a hoof problem that was associated with a selenium deficiency. This animal presented with quadriplegia. No significant alterations were observed at necropsy, although the classical FSPMS lesions were observed microscopically. The aim of this experiment was to study the neurotoxic effect of selenium in pigs.

\section{MATERIALS AND METHODS}

\section{Animals}

In 1994, fifteen Landrace pigs (two controls, S5 and S10) of both genders were used in the experiments. All of the animals were 45 to 120 days old and weighed between 7 and $24 \mathrm{~kg}$. The animals were kept in individual stalls $(1.5 \mathrm{~m} \times 1.5 \mathrm{~m})$. All animals were clinically healthy, and received commercial feed for swine (Purina) twice a day and free water ad libitum. Two animals were used as controls. The pigs were divided into three groups (G1, G2 and G3) according to the route used to administer the sodium selenite (Table 1).

Group G1. Four pigs (S1, S2, S3 and S4) received daily doses of commercial sodium selenite (E-Se and Myosel, Schering-Plough) by intramuscular injection in $0.84,1.41,1.68$ and $4.56 \mathrm{mg} \mathrm{Na}_{2} \mathrm{SeO}_{3}$ per kg body weight (bw) $(0.38,0.64,0.76$ and $2.08 \mathrm{mg}$ Se per $\mathrm{kg}$ bw) for 3 to 19 days, according to the presence and severity of their signs. The intramuscular sodium selenite doses were alternated between the neck and posterior parts of thigh.

Group G2. Four pigs (S6, S7, S8 and S9) received powdered $\mathrm{Se} / \mathrm{Na}_{2} \mathrm{SeO}_{3}$ mixed with their feed in concentrations of 111.1, 166.6, 222.2 and 277.7ppm (50.66, 75.97, 101.32 and 126.63ppm Se). The average daily dose was titrated to $2.70,3.54,4.38$ and $4.80 \mathrm{mg} \mathrm{Na}_{2} \mathrm{SeO}_{3} / \mathrm{kg}$ bw $(1.23,1.61,1.99$ and $2.18 \mathrm{mg} \mathrm{Se} / \mathrm{kg}$ bw) by controlling the amount of feed ingested. The period of ingestion varied according to the severity of the signs. Asymptomatic animals were euthanized 58 days after the beginning of the experiments.

Group G3. Five pigs (S11, S12, S13, S14 and S15), and sodium selenite was administrated intramuscularly (as in group G1) in an aqueous solution at concentrations of $11,32,10,26$ and $20 \%$. A $2.1 \mathrm{mg} \mathrm{Na}_{2} \mathrm{SeO}_{3} / \mathrm{kg}$ bw $(0.95 \mathrm{mg} \mathrm{Se} / \mathrm{kg} \mathrm{bw})$ dose was administered to animal S11, $1.7 \mathrm{mg} \mathrm{Na}_{2} \mathrm{SeO}_{3} / \mathrm{kg}$ bw $(0.77 \mathrm{mg} \mathrm{Se} / \mathrm{kg}$ bw $)$ to animals S12, S13 and S14, and a $1.1 \mathrm{mg} \mathrm{Na}_{2} \mathrm{SeO}_{3} / \mathrm{kg}$ bw $(0.50 \mathrm{mg} \mathrm{Se} /$ $\mathrm{kg} \mathrm{bw}$ ) dose to animal S15. The duration of the drug administration varied between three and 43 days, according to the clinical condition of each animal.

Before and during the experimental period, all of the animals were daily examined for general and neurological condition. The animals were humanly euthanized and immediately a necropsy was performed. Samples from all organs (brain, spinal cord, heart, lungs, kidneys, liver, spleen, adrenals, thyroid, pituitary, pancreas, eye, skeletal muscles, bladder and skin) were fixed in 10\% neutral buffered formalin for evaluation by light microscopy. The spinal cord samples from the S2, S6, S9 and control pigs were fixed in a 
chemically pure formalin solution for selenium analyses. The histological sections were prepared as previously described in this report.

One control pig (S5) received intramuscular daily injections of saline solution for 19 days. Both control pigs were euthanized at the end of experiment $\left(58^{\text {th }}\right.$ day after the beginning of the experiments).

\section{Chemical analysis}

Chemical analyses of selenium in nerve tissue (spinal cord) were performed by the National Center for Agroindustrial Technology Food Research (CTAA) of Embrapa, RJ.

\section{RESULTS}

Data regarding doses and clinical courses are shown in Table 1 . All doses caused signs in all the pigs of G1 that received the commercial sodium selenite. The lowest dose was $0.84 \mathrm{mg} \mathrm{Na}_{2} \mathrm{SeO}_{3} / \mathrm{kg}$ bw. The lowest dose that caused clinical signs in pigs of G3, the group that received an aqueous sodium selenite solution intramuscularly, was $1.7 \mathrm{mg} \mathrm{Na-}$ ${ }_{2} \mathrm{SeO}_{3} / \mathrm{kg}$ bw. Only two pigs (S7 and S9) were sick in G2. These pigs received sodium selenite compound in their feed. The lowest dose that caused symptoms in the experimental group was $3.54 \mathrm{mg} \mathrm{Na}_{2} \mathrm{SeO}_{3} / \mathrm{kg}$ bw. Nevertheless, the dosis of $4.38 \mathrm{mg} \mathrm{Na}_{2} \mathrm{SeO}_{3} / \mathrm{kg} \mathrm{BW}$ (S8) did not cause signs.

\section{Clinical findings}

The clinical course was peracute (less than four hours) in pigs of G1 which received the highest intramuscular dosage of commercial sodium selenite $\left(4,56 \mathrm{mg} \mathrm{Na}_{2} \mathrm{SeO}_{3} / \mathrm{kg}\right.$ BW). The other animals from G1 and the two other groups presented acute and subacute clinical signs, independent of the mode of administration.

Initially, apathy and decreased appetite were observed in animals of all three groups, followed by paresis and incoordination of the pelvic limbs (Fig.1). Neurological sings affected later thoracic limbs and, progressed to quadriplegia (Fig.1). These motor impairments were observed in pigs S1, S2, S3, S4, S7, S9, S11, S12, S13 and S14. In addition some pigs were reluctant to stand and usually presented abnormal postures, such a base-wide stance (S2) and low head (S2 and S3). Pig S7 stood with crossed limbs and leaned against a wall. Other neurological signs observed were vomiting (S4, S11 and S13), seizure followed by vomiting (S11), downward arching of the back (lordosis; S2, S3 and S7), muscular tremors (S2, S3, S4, S9 and S11), head tremors (S2 and S3), teeth grinding and chewing movements (S2), tongue (S2, S11 and S13) and lip (S2) twitching, hypersalivation (S4, S7, S11 and S13), mydriasis (S2, S11 and S13), diminished (S4) or absent (S11) palpebral reflexes, and nystagmus (S2 and S4). An absent pupillary light reflex, pelvic limb hypermetria that progressed to a stiff, sometimes backwards gait and pendulous head swinging were observed in S3. In S4, there was loss of cutaneous sensibility to pain in the hindquarters and thoracic limbs; tail sensibility was retained but could not invoke a reaction. Apnea was observed in the final stages of four animals (S2, S4, S11 and S13). In addition, some pigs presented congested ocular mucous membranes (S2, S4, S7 and S11), cyanosis (S1, S4 and S11), dyspnea (S1, S2, S4, S11 and S13), pain (S1 and S2) and swelling (S4) at the sodium selenite application site, rough and opaque skin with crust formation in some areas (S2). Pigs S2 and S7 showed slight improvement at the end of the clinical course, with relapse in 3-4 days and death occurring within 24-48 hours.

\section{Necropsy findings}

There was increased cerebro-spinal fluid (CSF) in three animals (S2, S7 and S8) and yellowish-brown areas in the horns of the cervical intumescence (S14) and in the mesencephalon (S14) (Fig.2). In group G2 (the group that received oral sodium selenite) the major lesions were observed in the liver. There were large irregular and pale areas. These areas either extended nearly $1 / 3$ of the organ (S6) or were restricted to small segments of the hepatic edge (S8) (Fig. 3). Pig S7 presented with lesions on the hooves that were characterized by a translucent corium, a purulent exudate

Table 1. Experimental sodium selenite poisoning in pigs

\begin{tabular}{|c|c|c|c|c|c|}
\hline Pig no. & $\begin{array}{c}\text { Daily dose of sodium selenite }\left(\mathrm{Na}_{2} \mathrm{SeO}_{3} \mathrm{H}_{2} \mathrm{O}\right) \\
\text { or Selenium }(\mathrm{Se})(\mathrm{mg} / \mathrm{kg})\end{array}$ & $\begin{array}{c}\text { Animal } \\
\text { weight (kg) }\end{array}$ & $\begin{array}{l}\text { Total daily dose of sodium } \\
\text { selenite or selenium (mg) }\end{array}$ & $\begin{array}{l}\text { Total time } \\
\text { (days) }\end{array}$ & $\begin{array}{l}\text { Total administered dose } \\
\text { sodium selenite or seleniun }\end{array}$ \\
\hline \multicolumn{6}{|c|}{ Group G1: Injectable sodium selenite - E-Se or Myosel-E* (IM route) } \\
\hline S1 & $4.56 / 2.08(10 \mathrm{ml})$ & 12 & $54.8 / 25.00$ & 3 & $164.4 / 74.96$ \\
\hline S2 & $0.84 / 0.38(2 \mathrm{ml})$ & 13 & $10.96 / 5.00$ & 19 & $208.24 / 94.95$ \\
\hline S3 & $1.68 / 0.76(3 \mathrm{ml})$ & 9.8 & $16.44 / 7.50$ & 6 & 98.64 / 44.97 \\
\hline S4 & $1.41 / 0.64(4 \mathrm{ml})$ & 15.5 & $21.92 / 10.00$ & 5 & $109.6 / 49.97$ \\
\hline S5 & Control & 13.5 & - & - & - \\
\hline \multicolumn{6}{|c|}{ Group G2: Sodium selenite and Selenium (ppm) in feed } \\
\hline S6 & $2.70 / 1.23(111.1 / 50.6 \mathrm{ppm})$ & 23.5 & $63.45 / 28.90$ & 58 & $3.680 .10 / 1.676 .20$ \\
\hline S7 & 3.54 / $1.61(166.66$ / 75.9 ppm $)$ & 21.5 & $76.11 / 34.61$ & 22 & $1.674,42$ / 761.42 \\
\hline S8 & 4.38 / $1.99(222.2$ / 101.3 ppm $)$ & 22.5 & 98.55 / 44.77 & 58 & $5.715 .90 / 2.596 .66$ \\
\hline S9 & 4.80 / $2.18(277.7$ / 126.6 ppm $)$ & 21.5 & $103.20 / 46.87$ & 14 & $1.444,80$ / 656.18 \\
\hline S10 & Control & 12.5 & - & - & - \\
\hline \multicolumn{6}{|c|}{ Group G3: Sodium selenite in distilled water (IM route) } \\
\hline S11 & $2.1 / 0.95(9 \mathrm{ml})$ & 19 & $39.90 / 18.05$ & 3 & $119.70 / 54.15$ \\
\hline S12 & $1.7 / 0.77(2.4 \mathrm{ml})$ & 7 & $11.90 / 5.39$ & 5 & $59.50 / 26.95$ \\
\hline S13 & 1.7 / 0.77 (8 ml) & 24 & $40.80 / 18.48$ & 5 & $204.00 / 92.40$ \\
\hline S14 & 1.7 / 0.77 (3 ml) & 9 & $15.30 / 6.93$ & 8 & $122.40 / 55.44$ \\
\hline S15 & $1.1 / 0.50(1.7 \mathrm{ml})$ & 7.5 & 8.25 / 3.75 & 43 & 354.75 / 161.25 \\
\hline
\end{tabular}

*E-Se and Myosel-E are trademarks of Schering-Plough. 
in the interdigital space and hyperemia of the junction of skin and hoof.

\section{Histopathology}

Significant histological lesions were found in the central nervous system, liver and heart. Nine pigs presented CNS and hepatic lesions (S3, S4, S5, S7, S9, S11, S12, 13 and 14).

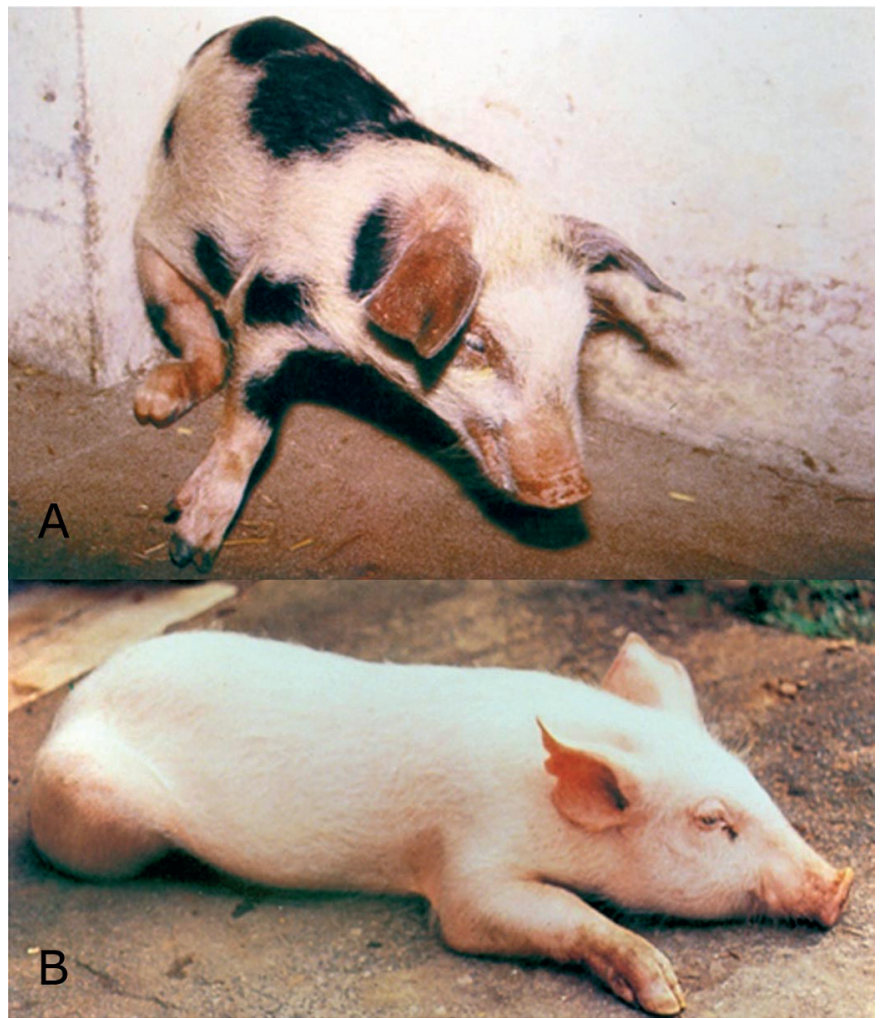

Fig.1. (A) Pig poisoned with intravenous administration of $\mathrm{Na}$ ${ }_{2} \mathrm{SeO}_{3} / \mathrm{kg} \mathrm{BW}$ showing marked rear leg paresis. Note that the animal is supporting with heels (S9). (B) Pig poisoned with intravenous administration of $\mathrm{Na}_{2} \mathrm{SeO}_{3} / \mathrm{kg} \mathrm{BW}$ showing marked tetraparesis (S7).

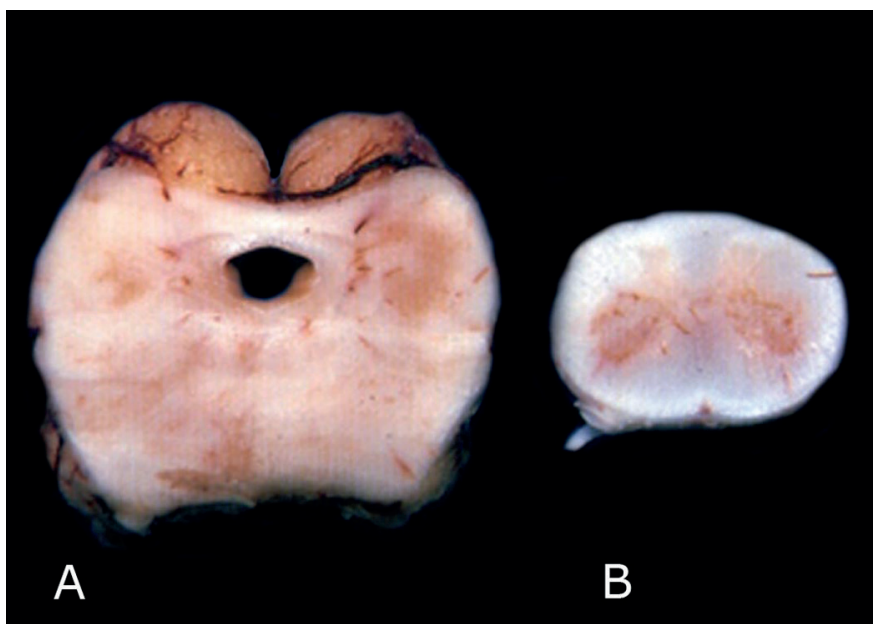

Fig.2. Pig experimentally poisoned with sodium selenite. (A) Mesencephalon at the level of the caudal colliculus, and (B) cervical intumescence showing bilateral symmetrical and locally extensive areas of malacia in the ventral horns, respectively (S14).

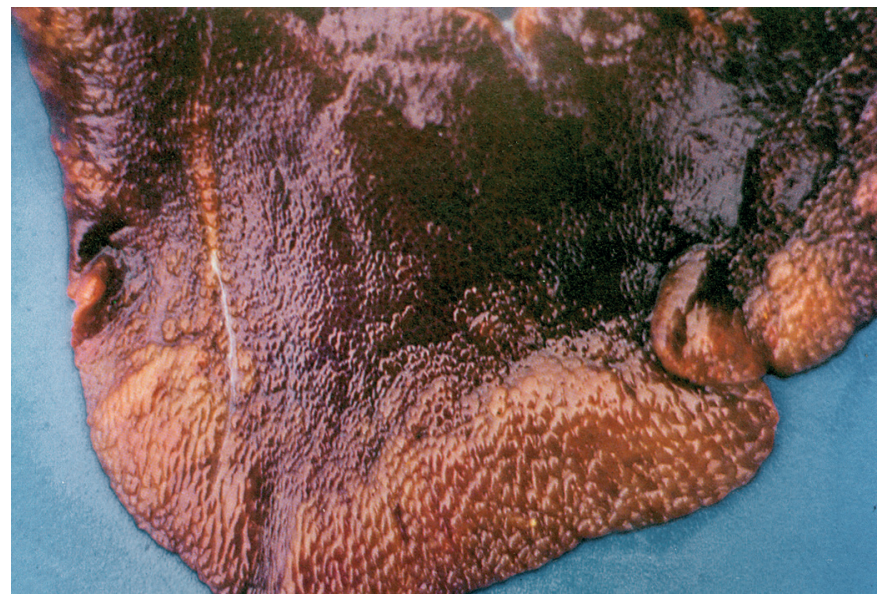

Fig.3. Pig experimentally poisoned with sodium selenite. Liver. Large irregular and pale areas at the edge (S6).
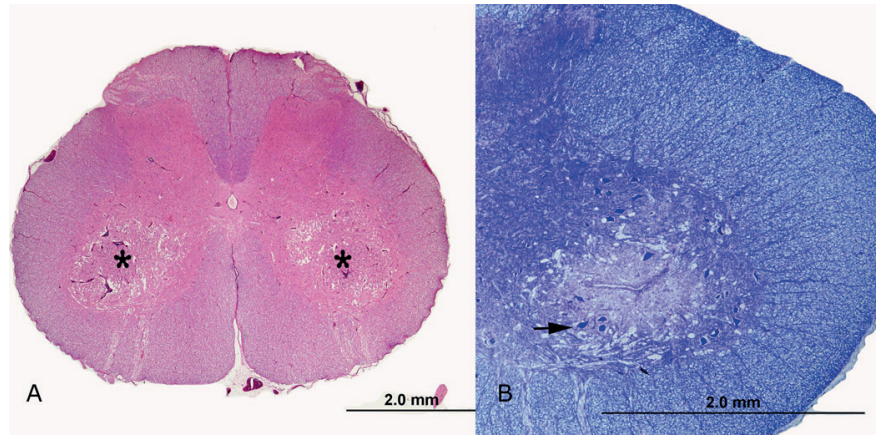

Fig.4. Pig experimentally poisoned with sodium selenite. Spinal cord at the level of the cervical intumescences with bilateral symmetric, locally extensive and severe necrosis affecting the ventral horns (asterisks). In (A) HE stain, obj. 2,5x (S12) and in (B) Luxol Fast Blue stain, obj.4x (S12). The arrow in B shows alpha-motor neurons still intact.

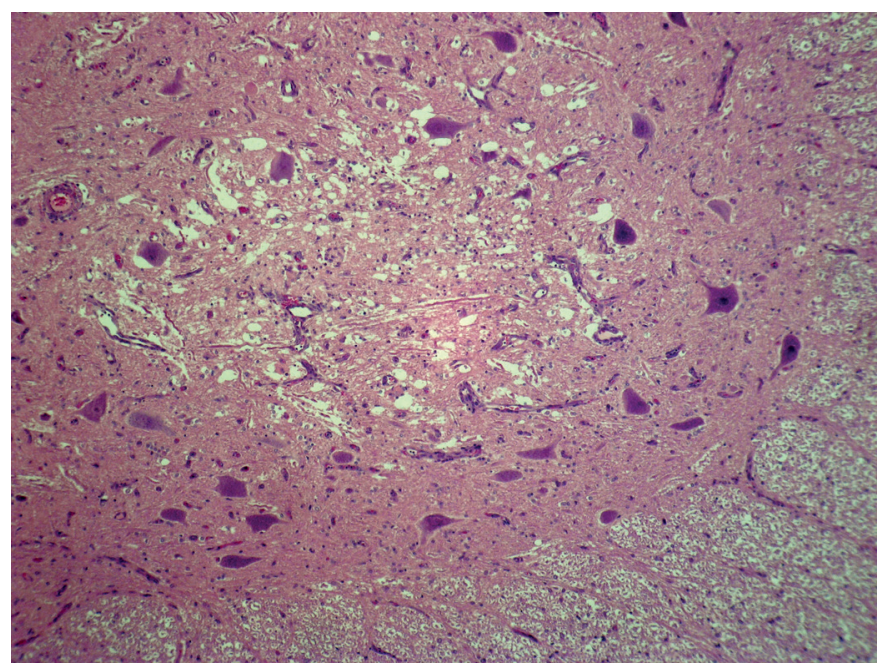

Fig.5. Pig experimentally poisoned with sodium selenite. Edema in the ventral horn of the cervical intumescence of spinal cord (S12). HE, obj.10x.

One pig presented CNS and cardiac lesions (S7). Two pigs presented only CNS lesions (S2 and S15). Two pigs presented only hepatic lesions (S6 and S8). One pig presented hepatic and cardiac lesions (S1 and S6). Microscopic lesions 
in the CNS, liver and heart of pig poisoning with sodium selenite is summarized in Table 2.

In the central nervous system the most significant microscopic finding was a bilateral, symmetrical, focal to segmental necrosis affecting mainly the gray matter of the spinal cord (S1, S3, S4, S5, S7, S9, S11, S12, 13 and 14; Fig.4), the brain stem (S1, S12, S13 and S14) and the mesencephalon (S1, S7, S9, S11, S13 and S14). The spinal cord lesions were locally extensive and more pronounced in the ventral horns, in the cervical and lumbar intumescences (Fig.4 and 5) (S1, S3, S4, S5, S7, S9, S11, S12, 13 and 14). Animals S1, S7, S9, S11, 13 and 14, presented lesion in spinal cord segments others than the cervical and lumbar intumescences. In the early stages of lesions, there was severe vascular permeability with degeneration and necrosis of neuron and astrocytes, and inflammatory infiltration, vascular proliferation and pannecrosis of the nerve tissue in the more advanced cases. In the early stages of lesions, degeneration of endothelial cells and muscular cell walls of blood vessels with formation of large perivascular space filled with fluid, fibrin and sometimes red blood cells, were the conspicuous (Fig.6). Astrocytes exhibited vesicular nuclei with marginated chromatin to picnosis, swollen, pale or eosinophilic plump cytoplasm (Fig.6 and 10). At this stage some neurons were detached from the neuropile, shrunken, hypereosinophilic (Fig.11) with fine cytoplasmic vacuolization with picnosis to kariolysis. With the progression of the lesions to a more severe and subchronic stage, the vacuolation neuropile (spongious aspect) (Fig.5) was more noticeable (Fig.6, 7 and 11), and astrocytes react with hyperplasia and hypertrophy (Fig.9). There was perivascular lymphocytic infiltration and microgliosis proliferation along with variable degree of macrophagic infiltration (Fig.7, 8 and 9).

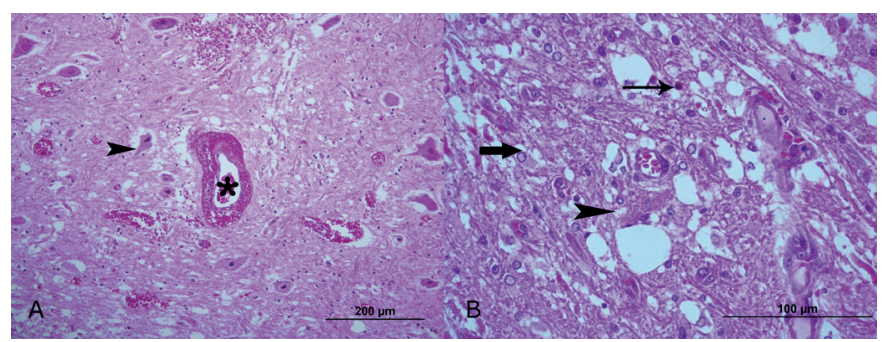

Fig.6. Pig experimentally poisoned with sodium selenite. Spinal cord at the level of the cervical intumescences. (A) Peracute lesion, blood vessels (asterisk) showing degeneration of endothelial cells and muscular cell walls with formation of large perivascular space filled with fluid, fibrin and red blood cells. (B) Acute lesion, astrocytes exhibited vesicular nuclei with marginated chromatin, eosinophilic, swollen, plump cytoplasm (fat arrow). An arrow indicates an eosinophil and the arrowhead signed a necrotic neuron. HE, obj.20x

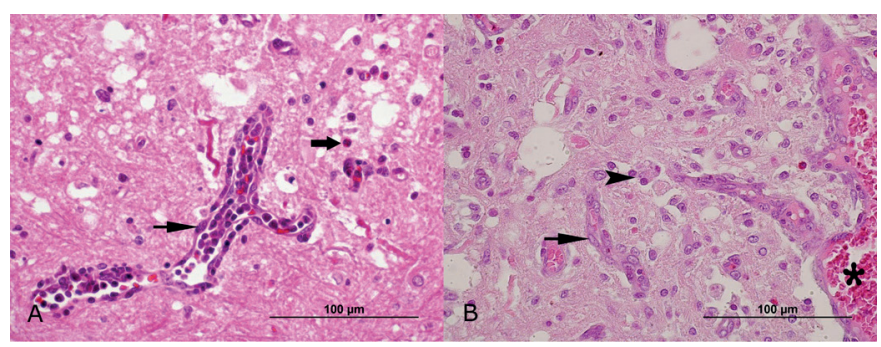

Fig.7. Pig experimentally poisoned with sodium selenite. Spinal cord at the level of the cervical intumescences. (A), Subchronic vascular reaction with endothelial hyperplasia and hypertrophy. Note a marked neuropile edema and intravascular and extravascular (fat arrow) leukocytic infiltration. (B) Chronic tissue reaction with endothelial hyperplasia and hypertrophy (arrow) and marked histiocytic infiltration (arrowhead). HE, obj.20x

Table 2. Microscopical lesions in the CNS, liver and heart of pigs experimentally poisoned with intramuscular and oral administration of sodium selenite

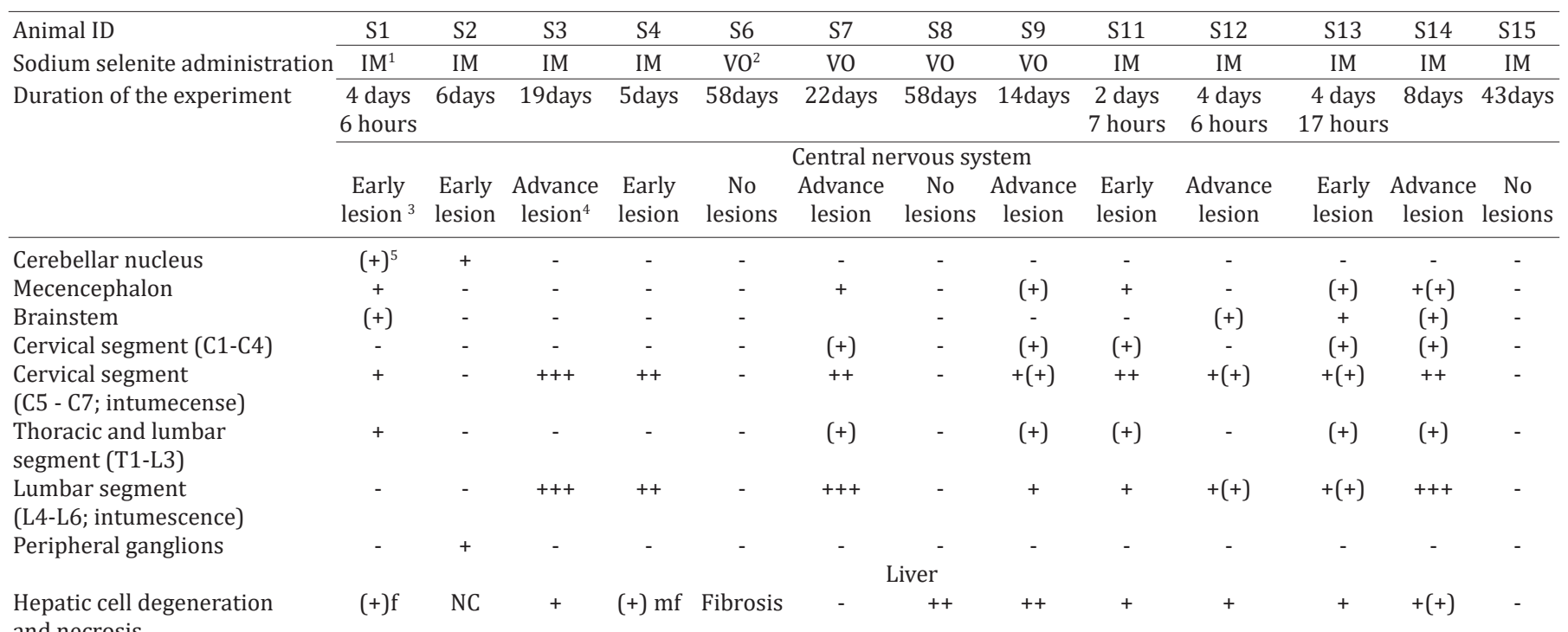
and necrosis

Myocardial necrosis

$+\mathrm{f}$

$+\mathrm{f}$

Heart

${ }^{1}$ Intramuscular administration; ${ }^{2}$ Oral administration; ${ }^{3}$ Early lesion predominate: Perivascular edema, astrocytic edema, neuropile edema with and without vacuolation, neuronal necrosis; ${ }^{4}$ Advance lesion predominate: pan necrosis (malacia), macrophage infiltration, vascular proliferation and endothelial activation; ${ }^{5}$ - no lesion, + mild lesion; ++ moderate lesion, +++ severe lesion; $\mathrm{f}=$ focal; $\mathrm{mf}=$ multifocal. 


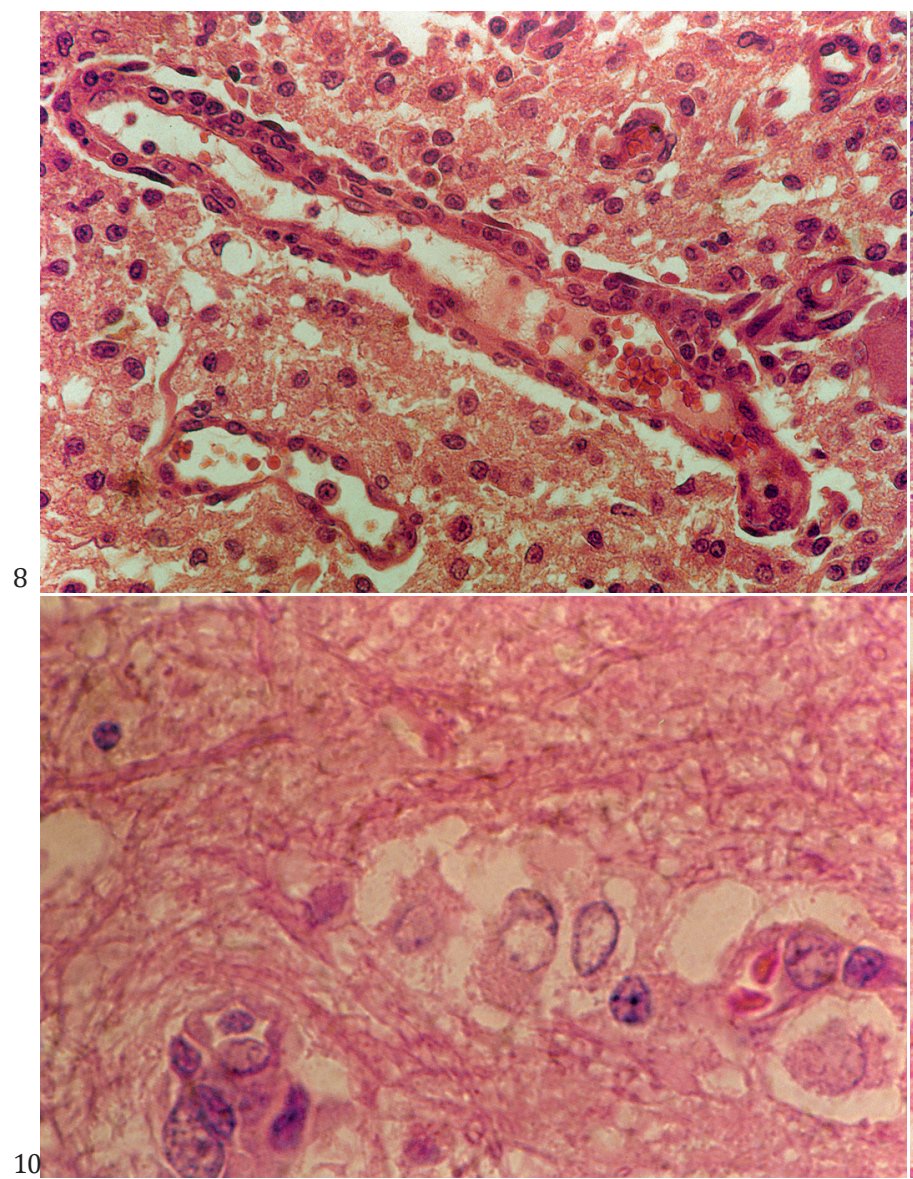

Fig.8. Pig experimentally poisoned with sodium selenite. Ventral horn of the spinal cord. Gliosis and incipient malacia; swollen endothelial (S7). HE, obj.40x.

Fig.9. Pig experimentally poisoned with sodium selenite. Gliosis, macrophage infiltration, and neuronal necrosis (focal malacia) (S7). HE, obj.20x.

Fig.10. Pig experimentally poisoned with sodium selenite. Astrocytes exhibited vesicular nuclei with marginated chromatin, swollen, eosinophilic cytoplasm (astrocytes edema). HE, obj.100x.

Fig.11. Pig experimentally poisoned with sodium selenite. Neuronal necrosis and astrocytes and neuropile edema. HE, obj.100x.

Fig.12. Pig experimentally poisoned with sodium selenite. Liver. The hepatic lesions consisted mainly of diffuse swelling hepatocytes with foci or midzonal areas of coagulative necrosis (S14). HE, obj.20x.

Neutrophils and eosinophils were present as well. There was vascular proliferation and also endothelial hyperplasia with cell hypertrophy (Fig.7). In the more chronic stages of the lesion, predominanted extensive areas of neuronal necrosis, neuronophagia, infiltration of large number of macrophages ("Gitter cells") and mononuclear perivascular cuffing (Fig.8, 9). Motor neurons were thus surprisingly preserved within and at the periphery of extensive areas of neuropile rarefaction and loss. Similar lesions were present in some areas of the mesencephalon and brain stem.

In the iatrogenically intoxicated animals, only the cervical and thoracic portions of the spinal cord were available
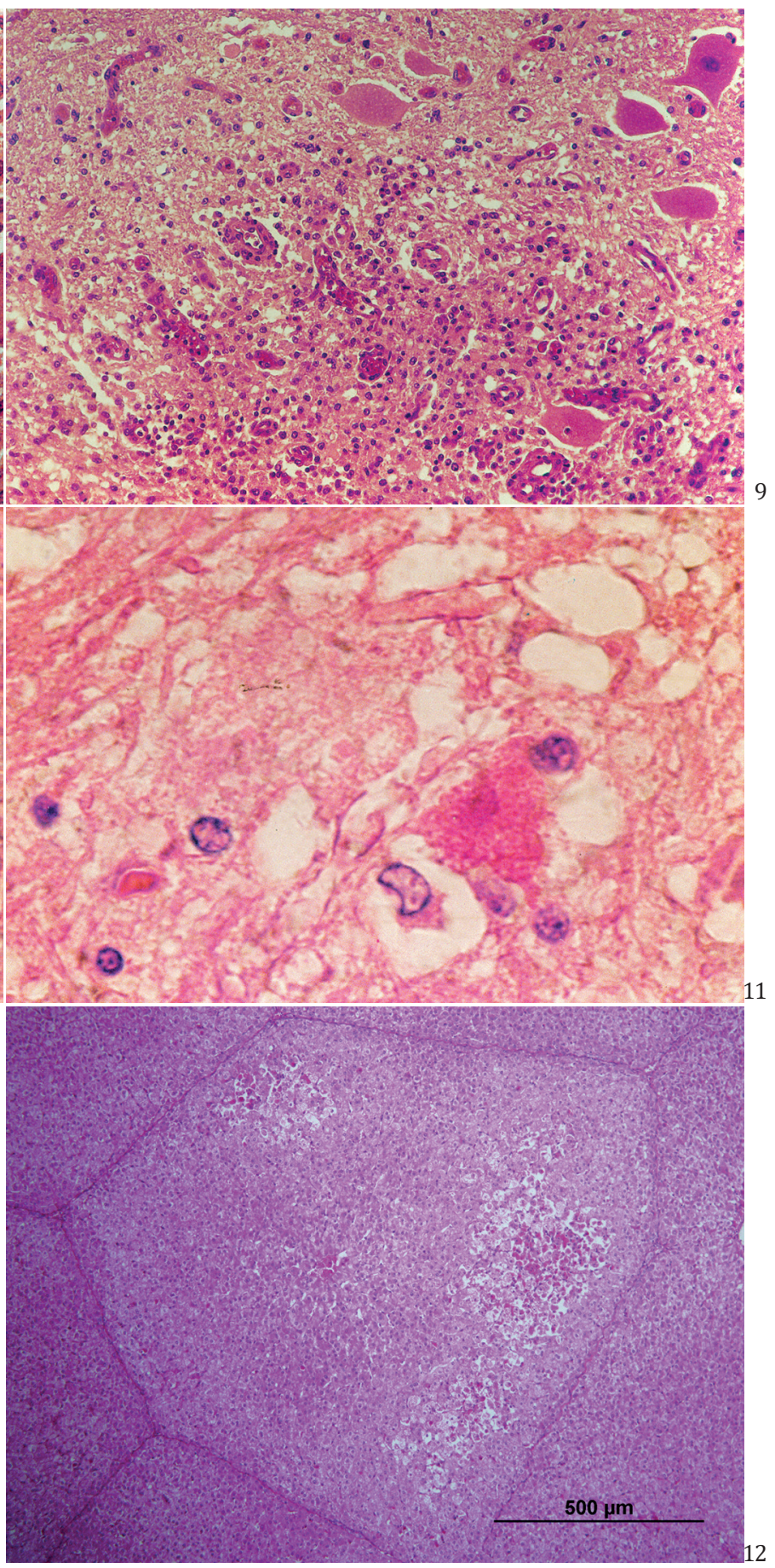

for histological examination. There was focal symmetrical poliomyelomalacia with large number of macrophages and neutrophils in the ventral horns of the spinal cord at the cervical intumescence.

The hepatic lesions consisted mainly of diffuse swelling hepatocytes with foci or small areas of coagulative necrosis (Fig.12); the distribution was random (S1, S3 and S8), periportal (S4, S12, S13, S14) or midzonal (S9, S12 and S14). Additionally, the $\mathrm{S} 6$ pig revealed incipient cirrhosis (slight fibrosis, regenerative nodules and the presence of megalocytes) mainly restricted to peripherical edge areas of the liver (Fig.13); other areas presented with the less dramatic 


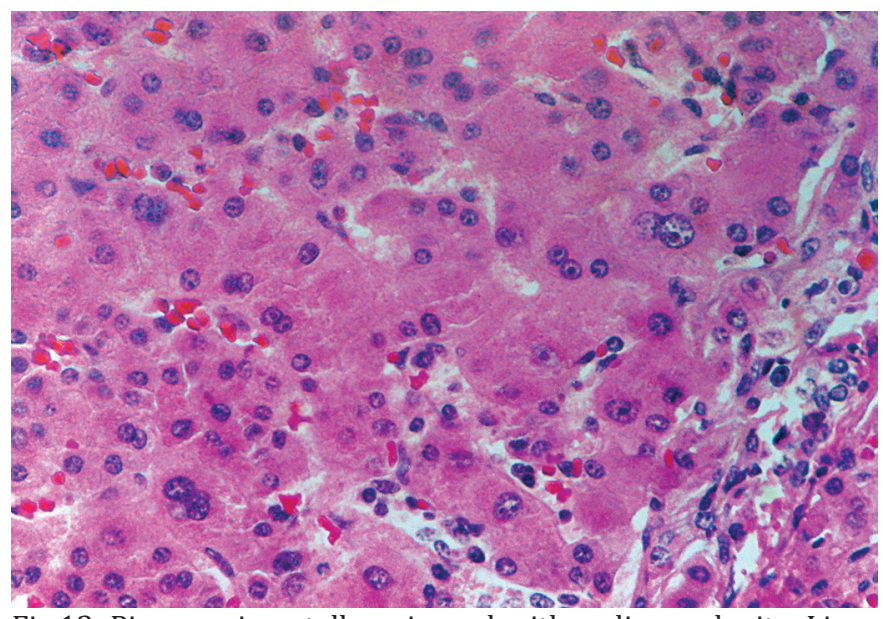

Fig.13. Pig experimentally poisoned with sodium selenite. Liver. Megalocytes and atypical hepatocytes (S6). HE, obj.40x.

alterations that were observed in the other animals. Three pigs (S1, S6 and S7) presented focal myocardial necrosis.

\section{Chemical analysis}

The results of the chemical analyses are shown in Table 3. There were high levels of selenium in the samples from pigs S2 and S9 (8.09 and 7.17ppm, respectively). Selenium was not detected in the spinal cord of the control animal (S5).

Table 3. Experimental sodium selenite intoxication in pig; analysis of selenium (ppm) in the spinal cord

\begin{tabular}{|c|c|c|c|}
\hline $\begin{array}{l}\text { Swine } \\
\text { No./SAP }\end{array}$ & $\begin{array}{l}\text { Se concentration } \\
\text { in the spinal } \\
\text { cord }(\mathrm{mg} / 100 \mathrm{~g})\end{array}$ & Methodology & $\begin{array}{c}\mathrm{Na}_{2} \mathrm{SeO}_{3} \text { and } \\
\text { Se doses used } \\
\text { (mg/kg) }\end{array}$ \\
\hline S2 & 8.09 & $\begin{array}{l}\text { Injectable sodium selenite - } \\
\text { commercial product (IM route) }\end{array}$ & $0.84 / 0.38$ \\
\hline S6 & 0.33 & Sodium selenite in feed & $2.70 / 1.23$ \\
\hline S9 & 7.17 & $\begin{array}{c}\text { Sodium selenite in } \\
\text { distilled water (IM route) }\end{array}$ & $4.80 / 2.18$ \\
\hline $\mathrm{SC}$ & Not detected & Control & - \\
\hline
\end{tabular}

\section{DISCUSSION}

The lesions found in the spinal cord of the present experimentally and iatrogenically poisoned pigs were identical to those found in FSPMS reported elsewhere (Harrison et al. 1983, Wilson et al. 1983, Casteel et al. 1985, Mensink et al. 1990, Stowe et al. 1992, Gomes et al. 2014).

The lowest dose administrated to the group (G1) receiving the commercial compound $\left(0.84 \mathrm{mg} \mathrm{Na}_{2} \mathrm{SeO}_{3} / \mathrm{kg} \mathrm{bw}\right)$ determined the onset of signs at 4 days 6 hours and a clinical course of about 14 days, at which point euthanasia was performed. The $1.7 \mathrm{mg} \mathrm{Na}_{2} \mathrm{SeO}_{3} / \mathrm{kg}$ bw dose administered to three of the animals in group G3 determined the onset of signs at between $27 \mathrm{~h} 40^{\prime}$ and $37 \mathrm{~h} 55^{\prime}$ and a clinical course of 5-8 days. The onset of signs was also relatively more rapid in the animals that received the aqueous solution, implying that the commercial vehicle liberated sodium selenite more slowly. The difference in the clinical courses of the three animals in group G3 indicates individual susceptibility.

In group $\mathrm{G} 2$, the average dose of $3.54 \mathrm{mg} \mathrm{Na} \mathrm{SeO}_{3} / \mathrm{kg}$ bw (corresponding to $166.6 \mathrm{ppm}$ of sodium selenite) in the feed led to death in 22 days. The average dose of $4.38 \mathrm{mg}$
$\mathrm{Na}_{2} \mathrm{SeO}_{3} / \mathrm{kg}$ bw (corresponding to $222.2 \mathrm{ppm}$ of sodium selenite) did not cause clinical signs in pig S8 after 58 days of feed ingestion, which reinforces the hypothesis of individual susceptibility.

Only two of the four pigs that received sodium selenite in their feed, with average doses of 3.54 and $4.80 \mathrm{mg} \mathrm{Na}_{2} \mathrm{SeO}_{3} /$ $\mathrm{kg}$ bw (corresponding to 166.6 and $277.7 \mathrm{ppm}$ of sodium selenite, respectively), developed signs. The main clinical features observed in this group were ataxia and paresis that progressed to paraplegia. Clinically, these pigs differed from those treated intramuscularly by absence of vomiting and hoof lesions. The pigs that received oral doses of 2.70 and $4.38 \mathrm{mg} \mathrm{Na}_{2} \mathrm{SeO}_{3} / \mathrm{kg}$ bw, doses more than twice as large as the lowest symptomatic intramuscular dose $11.7 \mathrm{mg}$ $\mathrm{Na}_{2} \mathrm{SeO}_{3} / \mathrm{kg} \mathrm{bw}$ ), remained asymptomatic for 58 days. Thus, parenteral administration appears to have a toxic potential almost three times greater than that of oral dosing. When we compared parenteral and oral administration, we verified that the largest oral dose, equivalent to $4.80 \mathrm{mg} \mathrm{Na}_{2} \mathrm{SeO}_{3} / \mathrm{kg}$ bw, led to an onset of signs in 13 days, although the clinical course was acute (lasting only one day). The lowest toxic parenteral dose $\left(1.7 \mathrm{mg} \mathrm{Na}_{2} \mathrm{SeO}_{3} / \mathrm{kg}\right.$ bw) was administrated to three pigs. It led to clinical signs in the second, third and seventh days. However, the clinical course was acute in all of these cases (lasting only one day). All of these data suggest a cumulative effect. By contrast, the longer clinical course associated with the commercial compound may have been attributable to slower liberation of the selenium.

It is known that the lowest toxic oral dose of selenium in swine is 4ppm (Hatch 1992) and that the maximum tolerated dose is 2ppm of selenium (Stowe et al. 1992). In 1998, the National Research Council (NRC) established 0.3mg of selenium per $\mathrm{kg}$ of feed $(0.3 \mathrm{ppm})$ as the maximum level for swine. On the basis of this recommendation, there would be a 13-fold safety margin before reaching the minimal toxic dose. In our experiments, the feed with 111.1 and $222.2 \mathrm{ppm}$ of sodium selenite powder containing $45.6 \%$ of elemental selenium (50.6 and 101.3ppm of selenium, respectively) supplied approximately 12 (12.6) and 50 (50.65) times more selenium than the minimum toxic dose and more than 168 (168.6) and 337 (337.6) times the dose we administrated for 58 days without observing symptoms. Although significant hepatic lesions were observed at necropsy and histopathology of the animal treated with the lowest dose; the animal that received 222.2ppm of sodium selenite (4.38 $\mathrm{mg} \mathrm{Na}_{2} \mathrm{SeO}_{3} / \mathrm{kg} \mathrm{bw}$ ) in its feed presented with milder lesions. Given these findings, it is not possible to affirm that risk of poisoning is elevated, nor that the safe limit is greater than the recommended maximum dose.

The parenteral administration results were similar to those for oral dosing; however, it is worth comparing our results with those from the literature. The recommended parenteral prophylactic dose is $0.06 \mathrm{mg} / \mathrm{kg}$ bw for piglets less than one week old and has to be repeated at weaning; female pigs should be dosed three weeks before going into labor (Radostits et al. 1994). The lowest lethal parenteral dose for normal pig in the literature is $1.4 \mathrm{mg} / \mathrm{kg}$ bw (Hatch 1992); for selenium-deficient pigs, it is between $0.9 \mathrm{mg} /$ kg asbw (Hatch 1992) and 1.0mg/kg bw (Hatch 1992, Ra- 
dostits et al. 1994). This range implies that the recommended dose is around 15 times greater than the lowest lethal dose. In the pigs treated with intramuscular sodium selenite in the current experiment, however, the lowest doses that led to death in one day were $1.7 \mathrm{mg} \mathrm{Na}_{2} \mathrm{SeO}_{3} / \mathrm{kg}$ bw for the aqueous solution and $0.84 \mathrm{mg} \mathrm{Na}_{2} \mathrm{SeO}_{3} / \mathrm{kg}$ bw for the commercial compound, values lower than the minimum toxic dose for deficient animals. It is not possible to attest that the pigs used in the present experiment did not have a subclinical selenium deficiency. The spinal cord chemical analysis for the control pig did not indicate the presence of selenium, although Baker et al. (1989) have reported between 0.4 and $0.37 \mathrm{ppm}$ in the spinal cord dry matter of the control animals in an experiment using selenium to induce FSPMS. Other findings from ill pigs have indicated 0.75 and $3.66 \mathrm{ppm}$ Se in the dry matter. One of the pigs in our experiment that received sodium selenite but did not became ill had $0.33 \mathrm{ppm}$ of selenium in its medulla's dry matter, which is similar to the values found by Baker et al. (1989) in the control swine; the animals that sickened had 7.17 and $8.09 \mathrm{ppm}$ of Se in their dry matter, much higher values than those found in the corresponding cases. Data on the selenium content of the spinal medulla are scarce and insufficient for drawing conclusions.

The microscopic spinal cord lesions are similar to those that have been described for FSPMS (Harrison et al. 1983, Wilson et al. 1983, Casteel et al. 1985, Mensink et al. 1990, Stowe et al. 1992, Gomes et al. 2014). There was endothelial degeneration and later activation, variable degrees of neuropil edema, neuronal necrosis, neuronophagia, macrophage infiltration, the occasional presence of eosinophils, mononuclear perivascular cuffing and severe gliosis with "Gitter cells". Given that the lesions were mainly distributed in the cervical and lumbar intumescences of the ventral horns of the spinal cord, we believe that disruption of the blood brain barrier with marked astrocyte edema and later pannecrosis in these regions could be a hallmark of FSPMS. However, the question of why the lesions occur largely in the intumescens remains to be answered. A possible explanation is that these intumescences require, independent of the biochemical mechanisms involved, a greater degree of vascular cells and astrocytic activity because of a greater concentration of motor neurons responsible for limb enervation (O'Sullivan \& Blakemore 1978, Cavanagh 1993, Summers et al. 1994).

In this way it is pertinent to compare with the chronic lead intoxication in human that similar in some aspect to pigs intoxicated with selenium, induce bilaterally symmetrical lesions in the CNS. More important, studies have demonstrated that the primary lead target is vascular. It has been hypothesized that the lead is taken up by the endothelial cells, alters their calcium homeostasis and inhibits cellular respiration, leading to abnormal permeability. Subsequently, lead damages the astrocytes and causes neuronal damage and edema. The endothelial changes induce to thrombosis, hemorrhage, edema, and parenchymal cell necrosis (Harris et al. 2008). In contrast to lead intoxication in human, thrombosis is not remarkable feature in pigs intoxicated with selenium.
The other significant alterations found were astrocyte edema and astrocyte proliferation. In this way, the astrocytes may be the cells initially harmed. When they astrocytes are cells initially damaged also a brakedown of the blood brain barrier is established (Summers et al. 1994, Harris et al. 2008).

The location of the lesions in the pons and in the intumescences, observed in the present study, suggests a specific energetic privation syndrome in which the highest risk of lesions occurs in the segments of the spinal cord with higher concentrations of neuronal bodies (Cavanagh 1993, Summers et al. 1994, Gomes et al. 2014). Cytoplasmic swelling in astrocytes, similar to that observed in pigs of the present study, occurs in areas where cells are metabolically compromised because of their association with functionally active or strongly stimulated neurons, although astrocytes of other regions can suffer from metabolic changes (Cavanagh 1993). Furthermore, the initial degeneration involving glial cells in the gray matter occur before neuronal necrosis. Astrocytic lesions can induce neuronal necrosis by nutritional deprivation and interruption of other astrocytic function such as decreased neuronal factor release and decreased glutamate uptake (Giulian et al. 1993, Bruijn et al. 2004). An immunohistochemical study of selenium intoxication in swine revealed that astrocytes with swollen nuclei are negative for GFAP and positive for S-100 protein, being characterized as Alzheimer type II (Gomes et al. 2014). In the final stages of lesions, there are astrocytes with increased expression of GFAP that participate in the reparative process (Gomes et al. 2014).

The theory of Wilson et al. (1983) on the relationship between selenium and niacin, in which a selenium excess leads to a niacin deficiency, seems logical and may explain the neurological and hepatic lesions. Niacin-induced deficiency culminates in decreased NAD and $\mathrm{NADH}_{2}$ coenzymes, which can interfere with carbohydrate, protein and fat metabolism. This system is known to be sensitive to energy deficiencies (Summers et al. 1994). This biochemical theory could be seen as complementary to those that highlight the role of astrocyte edema in the genesis of focal symmetrical poliomielomalacia of swines. Mean while, the preferential location of the spinal cord lesions in the intumescences may be explained by the anatomical aspects particular to swine mentioned above (Summers et al. 1994).

The hepatic alterations in the two animals treated with sodium selenite in their feed were severe. In the animal with the more severe macroscopic lesions (occupying a distinct $1 / 3$ of the hepatic area), the only sign was diminished appetite during the last 58 days of the experiment. Histopathologically, these animals also did not present with lesions in the central nervous system. The hepatic alterations mainly consisted of diffuse hepatocyte swelling, focal or locally extensive necrosis, and incipient cirrhosis with periportal fibrosis, presence of megalocytes and bizarre hepatocytes. These findings confirm that excessive selenium can cause severe hepatic lesions, as has been reported in some studies (Fitzhugh et al. 1944, Wahlstrom et al. 1955). It is interesting that both selenium deficiency and selenium poisoning can cause hepatic lesions in swine. Such hepatic lesions are important for the differential diagnosis because 
the conditions that can result in a similar histopathological picture, such as aflatoxin, pyrrolizidine alkaloid poisoning, are not rare (Stalker \& Hayes 2007). Since no vascular alterations were observed, the liver lesions may have been attributable to the direct toxic effect of the selenium.

The swine in this study had few skin and skin adnexal lesions, but those we observed were consistent with the lesions reported in the literature. Only one pig presented with hoof lesions, and another had dry and wrinkled skin. Although in this study there no evidence to support this hypothesis, it seems there is no doubt about the role of selenium in this kind of lesion caused by substitution of sulfur by selenium in sulfured amino acids and consequent abnormal protein synthesis (Hatch 1992, Ginnet al. 2007).

Acknowledgements.- To CNPq, FAPERJ and CAPES for the financial support and scholarship. The authors would like to thank Dr. Brian A. Summers, Professor of Pathology of Veterinary Medicine at Cornell University, for the valuable suggestions on this manuscript.

\section{REFERENCES}

Andrews E.D., Hartley W.J. \& Grant A.B. 1968. Selenium-responsive disease of animals in New Zealand. N.Z. Vet. J. 16:3-17.

Baker D.C., James L.F., Hartley W.J, Panter K.E., Maynard H.F. \& Pfister J. 1989. Toxicosis in pigs fed selenium-accumulating Astragalus plant species or sodium selenate. Am. J. Vet. Res. 50(8):1396-1399.

Beath O.A., Gilbert C.S. \& Eppson H.F. 1939. The use of indicator plants in locating seleniferous areas in western United States. I. General. Am. J. Bot. 26:257-269.

Bruijn L.I., Miller T.M. \& Cleveland D.W. 2004. Unraveling the mechanisms involved in motor neuron degeneration in ALS. Annu. Rev. Neurosci. 27:723-749.

Casteel S.W., Osweiler G.D., Cook W.O., Daniels G. \& Kadlec R. 1985. Selenium toxicosis in swine. J .Am. Vet .Med. Assoc. 186(10):1084-1085.

Cavanagh J.B. 1993. Seletive vulnerability in acute energy deprivation syndromes. Neuropathol. Appl. Neurobiol. 19(6):461-470.

Fitzhugh O.G., Nelson A.A. \& Bliss C.I. 1944. The chronic oral toxicity of selenium. J. Pharmacol. Exp. Therap. 80:289-299.

Franke K.W. \& Moxon A.L.A. 1936. Comparison of the minimum fatal doses of selenium, tellurium, arsenic and vanadium. J. Pharmacol. Exp. Therap. 58:454.

Gabbedy B.V. \& Dickson M.R.C.V.S. 1969. Acute selenium poisoning in lambs. Aust. Vet. J. 45:470-472.

Ginn P.E., Mansell J.E.K.L. \& Rakich P.M. 2007. The skin and appendages, p.553-782. In: Maxie M.G., Jubb K.V.F., Kennedy P.C. \& Palmer N.C. (Eds), Pathology of Domestic Animals. Vol.1. 5th ed. Saunder Elsever, New York.

Giulian D., Vaca K. \& Corpuz M. 1993. Brain glia release factors with opposing actions upon neuronal survival. J. Neurosci. 13(1):29-37.

Gomes D.C., Souza S.O., Juffo G.D., Pavarini S.P. \& Driemeier D. 2014. Intoxicação por selênio em suínos no sul do Brasil. Pesq. Vet. Bras. 34(12):1203-1209.
Harrison L.H., Colvin B.M., Stuart B.P., Sangster L.T., Gorgacz L. \& Gosser H.S. 1983. Paralysis in swine due to focal symmetrical poliomalacia possible selenium toxicosis. Vet. Pathol. 20(3):265-273.

Hatch R.C. 1992. Toxicologia veterinária, p.816-853. In.: Booth N.H. \& McDonald L.E. (Eds), Farmacologia e Terapêutica Aplicada em Veterinária. $6^{\mathrm{a}}$ ed. Guanabara Koogan, Rio de Janeiro.

Harris J., Chimelli L., Kril J. \& Ray D. 2008. Nutritional deficiencies, metabolic disorders and toxins affecting the nervous system, p.675-731. In: Love S., Louis D.V. \& Ellison D.W. (Eds), Grenfield's Neuropathology. 8th ed. Hodder Arnold, London.

Lambourne D.A. \& Mason R.W. 1969. Mortality in lambs following overdosing with sodium selenite. Aust. Vet. J. 45:208.

Mensink C.G., Koeman J.P., Veling J. \& Gruys E. 1990. Hemorrhagic claw lesions in newborn piglets due to selenium toxicosis during pregnancy. Vet. Rec. 126:620-622.

Morrow D.A. 1968. Acute selenite toxicosis in lambs. J. Am.Vet. Med. Assoc. 152(11):1625-1629.

Moxon A.L. \& Rhian M. 1943. Selenium poisoning. Physiological Reviews. 23(4):305-337.

O’Toole D., Raibeck M., Case J.C. \& Whitson T.D. 1996. Selenium-induced "Blind Staggers" and related myths: a commentary on the extend of historical livestock losses attributed to selenosis on western US Rangelands. Vet. Pathol. 33:104-116.

O'Sullivan B.M. \& Blakemore W.F. 1978. Acute nicotinamide deficiency in pigs. Vet. Rec. 103:543-544.

Penrith M.L. \& Robinson J.T.R. 1996. Selenium toxicosis with focal symmetrical poliomyelomalacia in postweaning pigs in South Africa. Onderstepoort J. Vet. Res. 63(2):171-179.

Petterson E.L., Milstrey R. \& Stokstad E.L.R. 1957. Effect os selenium in preventing, exudative diathesis in chicks. Proc. Society for Experimental Biology and Medicine, 95:617-620.

Radostits O.M., Blood D.C. \& Gay C.C. 1994. Veterinary Medicine, a text book of the disease of cattle, sheep, goats, pigs and horses. 8th ed. Balliere Tindall, London, UK. 1763p.

Schoening H.W. 1936. Production of so-called alkali disease in hogs by feeding corn grown in affected area. North Am. Vet. 17(9):22-28.

Shortridge E.H., O'hara P.J. \& Marshall P.M. 1971. Acute selenium poisoning in catlle. N.Z. Vet. J. 19:47-50.

Stowe H.D., Eavey A.J., Granger L., Halstead S. \& Yamini D. 1992. Selenium toxicosis in feeder pigs. J. Am. Vet. Med. Assoc. 201(2):292-295.

Stalker M.J. \& Hayes M.A. 2007. Liver and biliary system, p.297-388. In: Maxie M.G., Jubb K.V.F., Kennedy P.C. \& Palmer N.C. (Eds), Pathology of Domestic Animals. Vol.2. 5th ed. Saunders Elsevier, New York.

Summers B.A., Cummings J.F. \& Lahunta A. 1994. Veterinary Neuropathology. Mosby, Missouri. 527p.

Underwood E.J. 1983. Los minerales en la Nutrición de Ganado. $2^{a}$ ed, Acribia, Zaragoza, p.173-190.

Wahlstrom R.C., Kamstra L.D. \& Olson O.E. 1955. The effect of arsanilic acid and 3-nitro-4-hydroxyphenylarsonic acid on selenium poisoning in the pig.J. Anim. Sci. 14(1):105-117.

Wilson T.M., Scholz R.W. \& Drake T.R. 1983. Selenium toxicity and Porcine Focal Symmetrical Poliomyelomalacia: description of a field outbreak and experimental reproduction. Can. J. Comp. Med. 47:412-421. 